\title{
RAGE Does Not Contribute to Renal Injury and Damage upon Ischemia/ Reperfusion-Induced Injury
}

\author{
Mark C. Dessing ${ }^{a}$ Wilco P. Pulskens ${ }^{a} \quad G$ wendoline J. Teske ${ }^{a} \quad$ Loes M. Butter $^{a}$ \\ Tom van der Poll ${ }^{b}$ Huan Yang ${ }^{c}$ Kevin J. Tracey ${ }^{c}$ Peter P. Nawroth ${ }^{d}$ \\ Angelika Bierhaus $^{d}$ Sandrine Florquin ${ }^{a}$ Jaklien C. Leemans ${ }^{a}$ \\ ${ }^{\mathrm{a}}$ Department of Pathology and ${ }^{\mathrm{b}}$ Center for Infection and Immunity Amsterdam (CINIMA) and \\ Center for Experimental and Molecular Medicine, Academic Medical Center, University of Amsterdam, \\ Amsterdam, The Netherlands; ' Laboratories of Biomedical Science, Feinstein Institute for Medical Research, \\ Manhasset, N.Y., USA; ${ }^{\mathrm{d}}$ Department of Internal Medicine and Clinical Chemistry, University of Heidelberg, \\ Heidelberg, Germany
}

\section{Key Words}

Ischemia/reperfusion · Kidney · RAGE · HMGB1

\section{Abstract}

The receptor for advanced glycation end products (RAGE) mediates a variety of inflammatory responses in renal diseases, but its role in renal ischemia/reperfusion (I/R) injury is unknown. We showed that during renal I/R, RAGE ligands HMGB1 and S100B are expressed. However, RAGE deficiency does not affect renal injury and function upon I/R-induced injury.

Copyright $\odot 2011$ S. Karger AG, Basel

\section{Introduction}

Renal ischemia/reperfusion (I/R) is a major clinical problem and is the most common cause of acute renal failure after renal transplantation, shock, sepsis and renal artery stenosis [1]. I/R-induced injury is characterized by cell necrosis and release of endogenous molecules which are capable of activating the innate immune system through recognition by pattern-recognition receptors

\section{KARGER}

Fax +4161306 1234

E-Mail karger@karger.ch

www.karger.com
(C) 2011 S. Karger AG, Basel

1662-811X/12/0041-0080\$38.00/0

Accessible online at:

www.karger.com/jin
(PRR). The receptor for advanced glycation end products (RAGE) is a multiligand PRR that is expressed in all tissues and on a wide range of cell types, including renal mesangial cells, (proximal) tubuli, podocytes and Bowman's capsule [2-6] and mediates a variety of inflammatory responses in renal diseases [7]. RAGE blockade or deficiency has been shown to suppress hepatic, cardiac, lung and brain I/R-induced injury [8-12]; however, the contribution of RAGE in renal I/R-induced injury is unknown [13]. Therefore, in the current study we investigated the contribution of RAGE in renal I/R-induced injury.

\section{Methods}

Mice

Pathogen-free 9- to 10-week-old male C57BL/6 wild-type (WT) mice were purchased from Charles River Laboratories. RAGE knockout (RAGE KO) mice on a C57Bl/6 background (backcrossed ten times) were generated as described elsewhere

M.C. Dessing and W.P. Pulskens contributed equally to this paper. 
[14]. In RAGE KO mice, RAGE was deleted and replaced with a green fluorescent protein (GFP) construct. All mice were bred in the animal facility of the Academic Medical Center in Amsterdam, The Netherlands. Age- and sex-matched WT mice were used in all experiments as a control. The Animal Care and Use Committee of the University of Amsterdam approved all experiments.

\section{Renal I/R Injury Model}

Renal I/R injury was induced as described previously [15-17]. Briefly, both renal arteries were clamped for 30 min under general anesthesia $(0.07 \mathrm{ml} / 10 \mathrm{~g}$ mouse of fentanyl citrate fluanisone midazolam mixture containing: $1.25 \mathrm{mg} / \mathrm{ml}$ midazolam (Roche Diagnostics Corp.), $0.08 \mathrm{mg} / \mathrm{ml}$ fentanyl citrate, and $2.5 \mathrm{mg} / \mathrm{ml}$ fluanisone (Janssen Pharmaceutica)), which induces profound renal damage and dysfunction without inducing mortality [17]. All mice received a subcutaneous injection of $50 \mu \mathrm{g} / \mathrm{kg}$ buprenorphine (Temgesic; Schering-Plough). WT and RAGE KO mice were sacrificed 1, 5 or 10 days after I/R. Sham mice underwent the same procedure without clamping of the renal arteries and were sacrificed the following day. In separate experiments, WT mice were injected intraperitoneally with either anti-HMGB1 (high-mobility group box 1) antibodies, produced as described before [18, 19] (50 $\mu \mathrm{g}$ in $100 \mu \mathrm{l}$ phosphate-buffered saline total volume given 1 day before and immediately after I/R) or nonimmune mouse IgG2b antibodies (50 $\mu \mathrm{g}$ in $100 \mu \mathrm{l}$; Sigma-Aldrich, St. Louis, Mo., USA).

\section{Plasma Biochemical Analysis, Histology and}

Immunohistochemistry

Renal function and tubular damage was determined as described previously $[15,16]$. The degree of tubular damage was assessed on periodic acid-Schiff diastase (PASD)-stained paraffinembedded tissue sections. The PASD score represents tubular damage, which is visually characterized by necrosis, dilation, cast deposition and loss of brush border [20]. The degree of necrosis was scored by a pathologist in a blinded fashion on a 5-point scale: $0=$ no damage, $1=10 \%$ necrosis of the corticomedullary junction, $2=10-25 \%, 3=25-50 \%, 4=50-75 \%, 5=$ more than $75 \%$. For immunostaining, 4- $\mu \mathrm{m}$ tissue sections were incubated with specific antibodies for granulocytes (FITC-labeled anti-mouse Ly6G $\mathrm{mAb}$; BD Biosciences-Pharmingen), apoptosis (rabbit anti-human active caspase-3; Cell Signaling Technology), GFP (rabbitanti GFP IgG; Molecular Probes), HMGB1 (rabbit-anti mouse HMGB1; Abcam), S100B (rabbit anti-S100B; Sigma-Aldrich) or CML (N-epsilon carboxymethyl lysine) which has been identified as a major structure in advanced glycation end-products (AGE), mouse IgG, Biologo) followed by appropriate secondary antibodies as described before $[15,16,20-23]$. To determine percentage of positive staining on kidney tissue slides, approximately 10 pictures of tissue section were taken under light microscopy (magnification $\times 40$ ) and analyzed using a computer-assisted digital analysis program (ImageJ 1.45: Rasband, W.S., US National Institutes of Health, Bethesda, Md., USA).

\section{Preparation of Renal Tissue for Assays}

For cytokine measurements, snap-frozen kidneys were homogenized in lysis buffer $(300 \mathrm{mM} \mathrm{NaCl}, 30 \mathrm{mM}$ Tris, $2 \mathrm{mM}$ $\mathrm{MgCl}_{2}, 2 \mathrm{mM} \mathrm{CaCl}_{2}, 1 \%$ Triton X-100, and $1 \%$ protease inhibitor cocktail II; Sigma-Aldrich) as described previously $[15,16]$.
RAGE, neutrophil-related chemokines keratinocyte-derived chemokine (KC) and lipopolysaccharide-induced CXC chemokine (LIX) were measured using specific ELISAs (R\&D Systems) according to the manufacturer's instructions. To correct whole kidney homogenate for total protein content, the Bio-Rad Bradford Protein Assay (Bio-Rad Laboratories) was used with bovine gamma-globulin as standard.

\section{Statistics}

Differences between groups were analyzed using the MannWhitney $U$ test. Values are expressed as mean \pm SEM. $\mathrm{p}<0.05$ was considered statistically significant. Data are mean \pm SEM; sham group consists of 6 mice/group and I/R groups consist of 8-9 mice/group.

\section{Results}

\section{Expression and Localization of RAGE and RAGE}

Ligands in Kidney

To evaluate the influence of renal I/R injury on the expression and localization of RAGE, we studied RAGE KO mice, in which RAGE was deleted and replaced with a green fluorescent protein (GFP) construct [14]. Renal tissue slides were stained for GFP as surrogate marker for RAGE expression. As expected, kidney tissue slides from sham or I/R-subjected WT mice did not stain for GFP (data not shown), whereas RAGE KO mice displayed GFP-positive cells (fig. 1), i.e. cells normally expressing RAGE. Podocytes, distale tubuli and cells of the collecting duct stained positive for GFP. In WT mice, RAGE protein expression in whole kidney homogenate was significantly reduced 5 days after $\mathrm{I} / \mathrm{R}$ compared to sham WT mice (fig. 1f). In line, using photo digital analysis, the percentage of positive RAGE/GFP staining was lower on kidney tissue slides from RAGE KO mice 5 days after I/R compared to sham RAGE KO mice (\% positive staining/ HPF: sham $6.8 \pm 0.3 \%$ vs. I/R day five $2.7 \pm 0.7 \%$, p $<$ 0.005 , data are mean \pm SEM). Especially on distale tubuli, RAGE staining appeared to be reduced on kidney tissue slides from RAGE KO mice 5 days after I/R compared to sham RAGE KO mice (fig. 1d). Next, we determined expression and localization of RAGE ligands, HMGB1, S100B and AGE [7] in renal tissue slides from sham WT mice and WT mice 1,5 or 10 days after $\mathrm{I} / \mathrm{R}$ (fig. 2). Increased HMGB1 staining was observed in renal cells, 1 day after I/R which decreased thereafter. S100B staining was observed 5 days after I/R. Staining for AGE (using CML antibody as marker) was undetectable in kidney tissue slides from sham WT mice or WT mice 1,5 or 10 days after I/R (data not shown). 

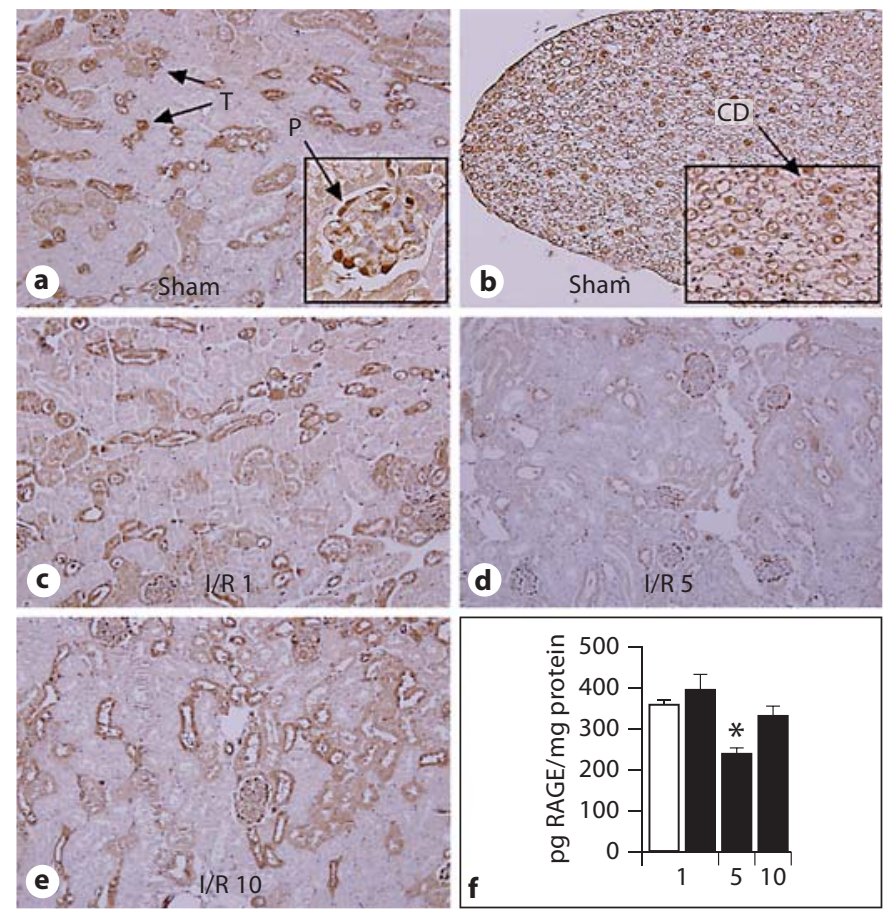

Fig. 1. RAGE expression and localization in kidney tissue. Representative picture of kidney tissue slides showing GFP staining in the renal cortex (a) and renal pelvis (b) of sham RAGE KO mice and in the renal cortex of RAGE KO mice 1 day (c), 5 days (d) and 10 days (e) after $\mathrm{I} / \mathrm{R}$ (magnification $\times 10$, inset $\mathrm{A}+\mathrm{B}$ magnification $\times 40$ ). In RAGE KO mice, GFP expression marks cells that typically express RAGE. $\mathrm{T}$ = Distal tubuli; $\mathrm{P}=$ podocyte; $\mathrm{CD}=$ collecting duct cell. RAGE protein expression in renal tissue homogenates (f) from sham WT mice (white bar) and from WT mice 1, 5 or 10 days after I/R (black bars). Data are mean $\pm \mathrm{SEM},{ }^{*} \mathrm{p}<$ 0.05 vs. sham mice.

\section{RAGE Deficiency Does Not Lead to Impaired Renal} Function after $I / R$

RAGE mediates a variety of inflammatory responses in renal diseases but its role in renal I/R injury has not been investigated yet $[7,13]$. We subjected WT and RAGE $\mathrm{KO}$ mice to renal $\mathrm{I} / \mathrm{R}$ and sacrificed them at different time-points. Typically, 1 day after severe I/R, plasma creatinine and urea levels increases which represents renal dysfunction. Thereafter, creatinine and urea levels return to basal level $[15,16]$. In line, tubular damage, characterized by necrosis, dilation, cast deposition, and loss of brush border increases upon I/R and reduces thereafter (fig. 3). Upon I/R, plasma creatinine and urea levels and tubular damage score were comparable in WT and RAGE $\mathrm{KO}$ mice at all time-points, indicating similar renal dysfunction and tubular damage between the two groups. Next, we measured apoptotic TECs, granulocyte influx and $\mathrm{KC}$ levels 1 day after $\mathrm{I} / \mathrm{R}$, the time-point most important for these parameters in this model [16]. The amount of apoptotic TECs in renal tissue sections, as displayed by caspase 3 staining, were not significantly different between WT and RAGE KO mice (fig. 4a). RAGE KO mice displayed more granulocytes in renal tissue sections, as displayed by Ly6 staining, and a higher level of KC in kidney homogenate compared to WT mice, 1 day after I/R (fig. 4b, c). Expression in whole kidney homogenate of another chemokine LIX, increased similar in WT and RAGE KO mice upon I/R (WT vs. RAGE KO: sham $22.7 \pm 1.6$ vs. $22.6 \pm 1.6, \mathrm{p}=1.00$ and $\mathrm{I} / \mathrm{R} 29.4 \pm 3.6$ vs. $30.1 \pm 3.0$, $\mathrm{p}=0.88$ ). These data implicate that upon $\mathrm{I} / \mathrm{R}, \mathrm{RAGE}$ does not significantly contribute to renal dysfunction, damage or apoptosis but affects inflammation to some extend.
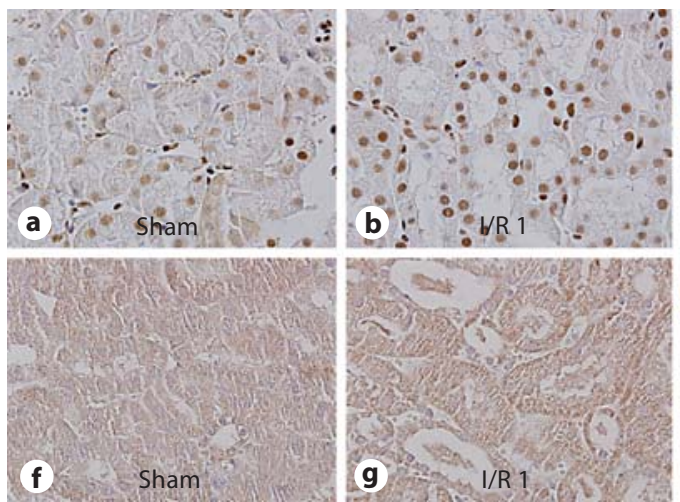
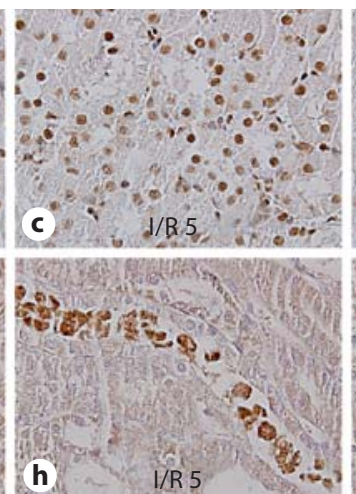
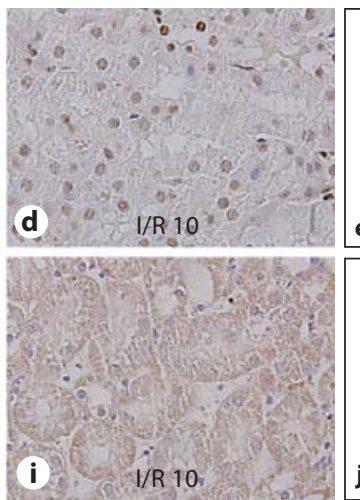

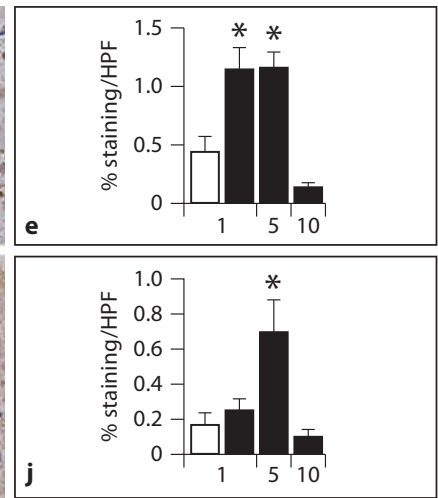

Fig. 2. RAGE ligands in WT mice subjected to I/R. Representative pictures of HMGB1 staining (a-d) and S100B staining (f-i) in kidney tissue sections from sham WT mice and WT mice 1, 5 and 10 days after I/R (magnification $\times 40$ ). Digital photo analysis of
HMGB1 (e) and S100B (j) staining on kidney tissue sections from sham WT mice (white bars) and WT mice 1, 5 or 10 days after I/R (black bars). Data are mean $\pm \mathrm{SEM},{ }^{*} \mathrm{p}<0.05$ vs. sham. 


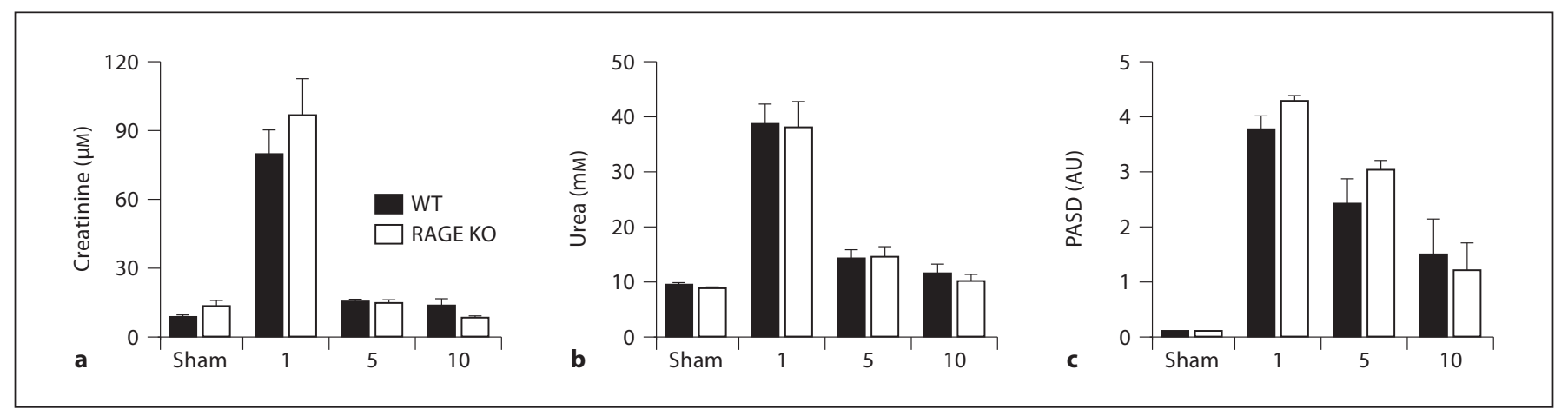

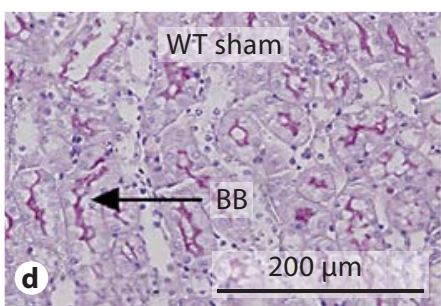

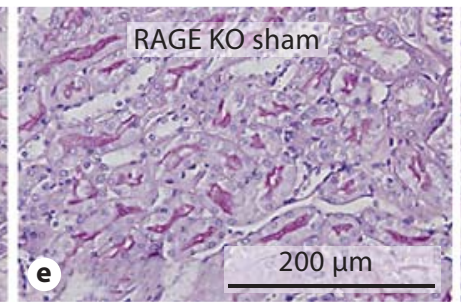

Fig. 3. Renal function and tubular damage in WT mice and RAGE KO mice subjected to I/R. Plasma levels of creatinine (a) and urea (b) and tubular damage (PASD; c) in WT (black bars) and RAGE KO mice (white bars) 1, 5 or 10 days after surgery. AU = arbitrary
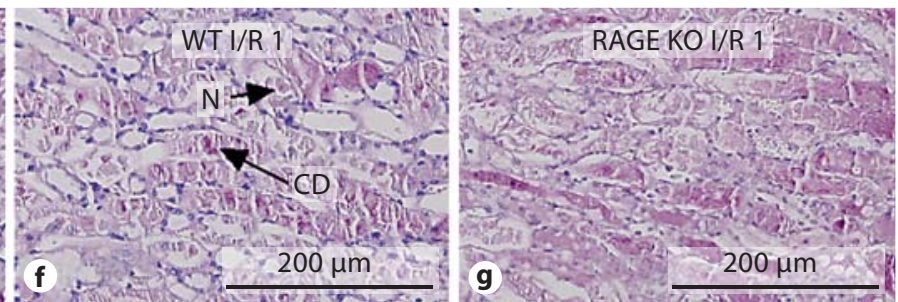

unit. Representative picture of PASD staining of renal tissue sections from WT mice $(\mathbf{d}, \mathbf{f})$ and RAGE KO mice $(\mathbf{e}, \mathbf{g}) 1$ day after $\operatorname{sham}(\mathbf{d}, \mathbf{e})$ or I/R $(\mathbf{f}, \mathbf{g})$ procedure. $\mathrm{N}=$ Necrosis; $\mathrm{CD}=$ cast deposition; $\mathrm{BB}=$ brush border.
Fig. 4. Renal inflammation in WT and RAGE KO mice subjected to I/R. Amount of apoptotic TECs (caspase 3; a) granulocytes (Ly6G; b) and levels of KC (c) in WT (black bars) and RAGE KO mice (white bars) 1 day after surgery. ${ }^{*} \mathrm{p}<0.01 \mathrm{vs.} \mathrm{WT}$.

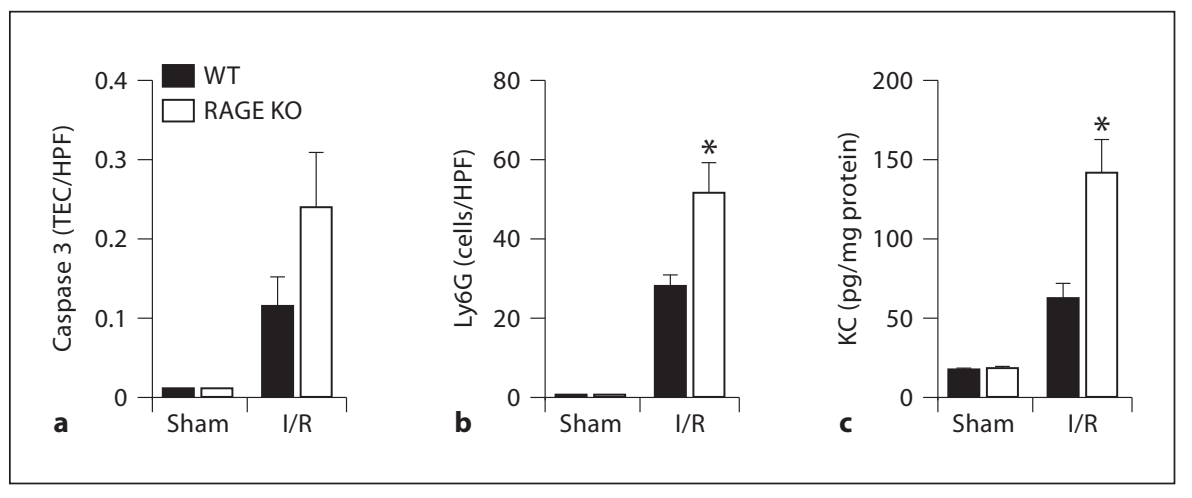

\section{RAGE Ligand HMGB1 Contributes to Renal I/R-Induced Injury}

HMGB1 is a high-affinity binding ligand for RAGE with cytokine activities and is implicated as one of the key players in the mechanism behind I/R-induced injury. HMGB1 staining on kidney tissue slides from WT and RAGE KO mice displayed a similar pattern in sham mice and in mice 1 day after I/R (fig. 2, data not shown). Treatment with HMGB1 antibodies reduced renal I/R-induced injury and dysfunction which was associated with reduced neutrophil influx and KC levels (for online suppl. fig. 1, see www.karger.com/doi/10.1159/000334251).

\section{Discussion}

Numerous studies have described the contribution of RAGE in I/R-induced injury in several organs other than in kidney [8-12]. RAGE is expressed in a wide range of renal cells and mediates a variety of inflammatory responses in renal diseases [7], but its role in renal I/R injury was unknown [13]. Therefore, we investigated the contribution of RAGE in renal I/R. We showed that RAGE ligands HMGB1 and S100B were expressed during I/R. Upon I/R, WT and RAGE KO mice were indistinguishable with respect to the primary renal endpoints: 
renal dysfunction and tubular damage. These findings indicate that the role of RAGE in I/R injury is tissue specific.

RAGE is a multiligand receptor of the immunoglobulin (Ig) superfamily and is expressed on a wide range of cell types, including renal mesangial cells, (proximal) tubuli, podocytes and Bowman's capsule $[3-6,13]$. In line with these results, we showed RAGE expression on podocyte and tubuli but also on cells of the collecting duct. Earlier studies have shown that RAGE expression was increased in heart, brain and liver following I/R injury $[8$, 12, 24-26]. We showed that RAGE expression in the kidney is unaltered early after I/R but is decreased 5 days after I/R. This shows that alteration in RAGE expression due to I/R-induced injury is different from other organs. RAGE deficiency did not influence renal dysfunction and damage upon I/R-induced injury. We did, however, observe higher KC level in the kidneys of RAGE KO mice compared to WT mice, 1 day after I/R. This was, however, not in line with another neutrophil-related proinflammatory chemokine LIX. How RAGE affects this distinctive proinflammatory response warrants further investigation.

Few studies have investigated RAGE ligand S100B in I/R. S100B expression was observed in ischemic heart disease [27]. S100B expression was also observed in myocardial infarction and S100B-deficient mice were beneficial to preservation of cardiac function herein [28]. Pelinka et al. [29] showed that circulating S100B levels increased several hours after renal I/R but did not describe expression in the kidney. We are the first to show S100B expression in the kidney following I/R. Its contribution herein remains to be investigated. We also determined the contribution of the most investigated endogenous RAGE ligand HMGB1 in renal I/R. In line with previous findings $[30,31]$, we showed that blocking HMGB1 reduces renal I/R-induced injury by dampening the inflammatory response. As we do not see a similar phenotype in RAGE KO mice, the effect of HMGB1 in renal I/R injury cannot be explained by RAGE signaling. HMGB1 can, however, also induce activation of intracellular signaling pathways via interaction with PRRs other than RAGE including: Toll-like receptor (TLR) 2, TLR-4 and inflammasome NACHT, LRR and PYD domains-containing protein 3 (Nlrp3) $[32,33]$. We and others have shown that $\alpha$ HMGB1-treated WT mice, TLR2 KO, TLR4 KO and Nlrp3 KO mice display a similar phenotype following renal I/R [16, 17, 21, 30, 31, 34-36]. Together, these reports implicate that the deleterious effect of HMGB1 in the development of renal I/R injury is not mediated by RAGE signaling, but rather by TLRs and/or Nlrp3. Therefore, targeting HMGB1 and not RAGE would provide a potential therapeutic strategy to prevent or slow down renal I/R injury. This study further clarified the mechanism by which HMGB1 induces renal I/R-induced injury.

\section{References}

1 Alkhunaizi AM, Schrier RW: Management of acute renal failure: new perspectives. Am J Kidney Dis 1996;28:315-328.

2 Kalea AZ, Reiniger N, Yang H, Arriero M, Schmidt AM, Hudson BI: Alternative splicing of the murine receptor for advanced glycation end-products (RAGE) gene. Faseb J 2009;23:1766-1774.

3 Gefter JV, Shaufl AL, Fink MP, Delude RL: Comparison of distinct protein isoforms of the receptor for advanced glycation endproducts expressed in murine tissues and cell lines. Cell Tissue Res 2009;337:79-89.

-4 Harashima A, Yamamoto Y, Cheng C, Tsuneyama K, Myint KM, Takeuchi A, Yoshimura K, Li H, Watanabe T, Takasawa S, Okamoto $\mathrm{H}$, Yonekura $\mathrm{H}$, Yamamoto $\mathrm{H}$ : Identification of mouse orthologue of endogenous secretory receptor for advanced glycation end-products: structure, function and expression. Biochem J 2006;396:109115.
5 Brett J, Schmidt AM, Yan SD, et al: Survey of the distribution of a newly characterized receptor for advanced glycation end products in tissues. Am J Pathol 1993;143:1699-1712.

-6 Guo J, Ananthakrishnan R, Qu W, Lu Y, Reiniger N, Zeng S, Ma W, Rosario R, Yan SF, Ramasamy R, D’Agati V, Schmidt AM: Rage mediates podocyte injury in adriamycin-induced glomerulosclerosis. J Am Soc Nephrol 2008;19:961-972.

7 D'Agati V, Schmidt AM: Rage and the pathogenesis of chronic kidney disease. Nat Rev Nephrol 2010;6:352-360.

$>_{8}$ Zeng S, Feirt N, Goldstein M, Guarrera J, Ippagunta N, Ekong U, Dun H, Lu Y, Qu W, Schmidt AM, Emond JC: Blockade of receptor for advanced glycation end product (RAGE) attenuates ischemia and reperfusion injury to the liver in mice. Hepatology 2004; 39:422-432.
Andrassy M, Volz HC, Igwe JC, Funke B, Eichberger SN, Kaya Z, Buss S, Autschbach F, Pleger ST, Lukic IK, Bea F, Hardt SE, Humpert PM, Bianchi ME, Mairbaurl H, Nawroth PP, Remppis A, Katus HA, Bierhaus A: High-mobility group BOX-1 in ischemiareperfusion injury of the heart. Circulation 2008;117:3216-3226.

-10 Sternberg DI, Gowda R, Mehra D, Qu W, Weinberg A, Twaddell W, Sarkar J, Wallace A, Hudson B, D'Ovidio F, Arcasoy S, Ramasamy R, D'Armiento J, Schmidt AM, Sonett JR: Blockade of receptor for advanced glycation end product attenuates pulmonary reperfusion injury in mice. J Thorac Cardiovasc Surg 2008;136:1576-1585.

11 Muhammad S, Barakat W, Stoyanov S, Murikinati S, Yang H, Tracey KJ, Bendszus M, Rossetti G, Nawroth PP, Bierhaus A, Schwaninger M: The HMGB1 receptor RAGE mediates ischemic brain damage. J Neurosci 2008;28:12023-12031. 
$\checkmark 12$ Hassid BG, Nair MN, Ducruet AF, Otten ML, Komotar RJ, Pinsky DJ, Schmidt AM, Yan SF, Connolly ES: Neuronal RAGE expression modulates severity of injury following transient focal cerebral ischemia. J Clin Neurosci 2009;16:302-306.

$\checkmark 13 \mathrm{Lu}$ CY, Hartono J, Senitko M, Chen J: The inflammatory response to ischemic acute kidney injury: a result of the 'right stuff' in the 'wrong place'? Curr Opin Nephrol Hypertens 2007;16:83-89.

- 14 Liliensiek B, Weigand MA, Bierhaus A, Nicklas W, Kasper M, Hofer S, Plachky J, Grone HJ, Kurschus FC, Schmidt AM, Yan SD, Martin E, Schleicher E, Stern DM, Hammerling GG, Nawroth PP, Arnold B: Receptor for advanced glycation end products (RAGE) regulates sepsis but not the adaptive immune response. J Clin Invest 2004;113: 1641-1650.

15 Rouschop KM, Roelofs JJ, Claessen N, da Costa Martins P, Zwaginga JJ, Pals ST, Weening JJ, Florquin S: Protection against renal ischemia reperfusion injury by CD44 disruption. J Am Soc Nephrol 2005;16:20342043.

16 Leemans JC, Stokman G, Claessen N, Rouschop KM, Teske GJ, Kirschning CJ, Akira S, van der Poll T, Weening JJ, Florquin S: Renalassociated TLR2 mediates ischemia/reperfusion injury in the kidney. J Clin Invest 2005; 115:2894-2903.

17 Iyer SS, Pulskens WP, Sadler JJ, Butter LM, Teske GJ, Ulland TK, Eisenbarth SC, Florquin S, Flavell RA, Leemans JC, Sutterwala FS: Necrotic cells trigger a sterile inflammatory response through the NLRP3 inflammasome. Proc Natl Acad Sci USA 2009;106: 20388-20393.

18 Yang H, Ochani M, Li J, Qiang X, Tanovic M, Harris HE, Susarla SM, Ulloa L, Wang H, DiRaimo R, Czura CJ, Roth J, Warren HS, Fink MP, Fenton MJ, Andersson U, Tracey KJ: Reversing established sepsis with antagonists of endogenous high-mobility group box 1. Proc Natl Acad Sci USA 2004;101:296-301.

19 van Zoelen MA, Achouiti A, Schmidt AM, Yang H, Florquin S, Tracey KJ, van der Poll T: Ligands of the receptor for advanced glycation end products, including high-mobility group box 1, limit bacterial dissemination during Escherichia coli peritonitis. Crit Care Med 2010;38:1414-1422.
20 Sadis C, Teske G, Stokman G, Kubjak C, Claessen N, Moore F, Loi P, Diallo B, Barvais L, Goldman M, Florquin S, Le Moine A: Nicotine protects kidney from renal ischemia/ reperfusion injury through the cholinergic anti-inflammatory pathway. PLoS ONE 2007;2:e469.

21 Pulskens WP, Teske GJ, Butter LM, Roelofs JJ, van der Poll T, Florquin S, Leemans JC: Toll-like receptor-4 coordinates the innate immune response of the kidney to renal ischemia/reperfusion injury. PLoS ONE 2008; 3:e3596.

22 Roelofs JJ, Rouschop KM, Leemans JC, Claessen N, de Boer AM, Frederiks WM, Lijnen HR, Weening JJ, Florquin S: Tissuetype plasminogen activator modulates inflammatory responses and renal function in ischemia reperfusion injury. J Am Soc Nephrol 2006;17:131-140.

23 Stokman G, Leemans JC, Claessen N, Weening JJ, Florquin S: Hematopoietic stem cell mobilization therapy accelerates recovery of renal function independent of stem cell contribution. J Am Soc Nephrol 2005;16:16841692.

24 Bucciarelli LG, Kaneko M, Ananthakrishnan R, Harja E, Lee LK, Hwang YC, Lerner S, Bakr S, Li Q, Lu Y, Song F, Qu W, Gomez T, Zou YS, Yan SF, Schmidt AM, Ramasamy $\mathrm{R}$ : Receptor for advanced-glycation end products: key modulator of myocardial ischemic injury. Circulation 2006;113:12261234.

25 Pichiule P, Chavez JC, Schmidt AM, Vannucci SJ: Hypoxia-inducible factor-1 mediates neuronal expression of the receptor for advanced glycation end products following hypoxia/ischemia. J Biol Chem 2007;282: 36330-36340.

26 Aleshin A, Ananthakrishnan R, Li Q, Rosario R, Lu Y, Qu W, Song F, Bakr S, Szabolcs M, D’Agati V, Liu R, Homma S, Schmidt AM, Yan SF, Ramasamy R: RAGE modulates myocardial injury consequent to LAD infarction via impact on JNK and STAT signaling in a murine model. Am J Physiol Heart Circ Physiol 2008;294:H1823-H1832.

27 Mazzini GS, Schaf DV, Oliveira AR, Goncalves CA, Bello-Klein A, Bordignon S, Bruch RS, Campos GF, Vassallo DV, Souza DO, Portela LV: The ischemic rat heart releases S100B. Life Sci 2005;77:882-889.
28 Tsoporis JN, Marks A, Haddad A, Dawood F, Liu PP, Parker TG: S100B expression modulates left ventricular remodeling after myocardial infarction in mice. Circulation 2005; 111:598-606

29 Pelinka LE, Harada N, Szalay L, Jafarmadar M, Redl H, Bahrami S: Release of S100B differs during ischemia and reperfusion of the liver, the gut, and the kidney in rats. Shock 2004;21:72-76.

30 Li J, Gong Q, Zhong S, Wang L, Guo H, Xiang Y, Ichim TE, Wang CY, Chen S, Gong F, Chen G: Neutralization of the extracellular HMGB1 released by ischaemic damaged renal cells protects against renal ischaemia-reperfusion injury. Nephrol Dial Transplant 2011;26:469-478.

$31 \mathrm{Wu}$ H, Ma J, Wang P, Corpuz TM, Panchapakesan U, Wyburn KR, Chadban SJ: HMGB1 contributes to kidney ischemia reperfusion injury. J Am Soc Nephrol 2010;21: 1878-1890.

32 Yu M, Wang H, Ding A, Golenbock DT, Latz E, Czura CJ, Fenton MJ, Tracey KJ, Yang H: Hmgbl signals through Toll-like receptor (TLR) 4 and TLR2. Shock 2006;26:174-179.

33 Ghiringhelli F, Apetoh L, Tesniere A, Aymeric L, Ma Y, Ortiz C, Vermaelen K, Panaretakis T, Mignot G, Ullrich E, Perfettini JL, Schlemmer F, Tasdemir E, Uhl M, Genin P, Civas A, Ryffel B, Kanellopoulos J, Tschopp J, Andre F, Lidereau R, McLaughlin NM, Haynes NM, Smyth MJ, Kroemer G, Zitvogel L: Activation of the NLRP3 inflammasome in dendritic cells induces IL-1beta-dependent adaptive immunity against tumors. Nat Med 2009;15:1170-1178.

-34 Shigeoka AA, Holscher TD, King AJ, Hall FW, Kiosses WB, Tobias PS, Mackman N, McKay DB: TLR2 is constitutively expressed within the kidney and participates in ischemic renal injury through both MYD88-dependent and -independent pathways. J Immunol 2007;178:6252-6258.

35 Wu H, Chen G, Wyburn KR, Yin J, Bertolino P, Eris JM, Alexander SI, Sharland AF, Chadban SJ: TLR4 activation mediates kidney ischemia/reperfusion injury. J Clin Invest 2007;117:2847-2859.

36 Rusai K, Sollinger D, Baumann M, Wagner B, Strobl M, Schmaderer C, Roos M, Kirschning C, Heemann U, Lutz J: Toll-like receptors 2 and 4 in renal ischemia/reperfusion injury. Pediatr Nephrol (Berlin) 2010; 25:853-860. 